\title{
Sistem DACUM pri sestavljanju strokovnih izobraževalnih programov
}

\author{
Jindra Kulich
}

\begin{abstract}
Sistem DACUM je razmeroma nov sistem logično razvrščenih postopnih korakov, ki jih je mogoče uporabiti za večjo učinkovitost pri strokovnem izobraževanju delavcev.
\end{abstract}

Sistem DACUM ponuja organizacijski načrt, ki ima naslednje ugodnosti:

1. Učitelju (mentorju) se ni treba opirati samo na lastne izkušnje, temveč lahko črpa tudi iz ekspertize in izkušenj drugih učiteljev (mentorjev) pa tudi iz izkušenj strokovnih delavcev določenega področja.

2. Delovne naloge in zahteve so razčlenjene in izobraževanje je načrtovano tako, da je udeleženec, ki gre skozi učni proces, zmožen opravljati naloge, določene $\mathrm{z}$ delovnim mestom. Kvalifikacija udeležencev, ki bodo uspešno dokončali izobraževalni tečaj (ali več tečajev), je v skladu s kvalifikacijo, ki jo v ustrezni stroki predpisujejo trgovska oziroma industrijska podjetja. Sodelovanje med izobraževalnim sistemom oziroma ustanovo ter med trgovino in industrijo pomaga oblikovati realne cilje za vsak strokovnoizobraževalni tečaj (vrsto tečajev).

3. Postopek DACUM je dosleden in sistematičen. Vsa opravila in naloge, ki jih bo moral delavec opravljati na delovnem mestu, so opisane in razčlenjene v obvladljive segmente za lažje izobraževanje in učenje. Učitelju je omogočeno, da na tečaju pusti udeležencem ravnati z učnim gradivom samostojno, da pridobivajo znanje in spretnosti pri opravljanju delovnih nalog $\mathrm{v}$ lastnem času (s svojo lastno hitrostjo).

4. Sestavljanje učnih načrtov ves čas spremljajo delodajalci, strokovnjaki določenega področja, mentorji in izvedenci ter preverjajo ustreznost vsebine pri izobraževanju.

Postopek DACUM je sestavljen iz petih korakov. Pri prvih dveh sodelujejo sestavljalci učnih načrtov in strokovni delavci določenega poklicnega področja. Gre za

1. analizo delovnih nalog in

2. določitev storilnostnih ciljev.

Pri naslednjih treh korakih gre za učiteljevo (mentorjevo) uporabo in prirejanje izdelanih izobraževalnih programov. Izbrati mora:

3. postopek vrednotenja,

4. primerne učne metode,

5. izobraževalna sredstva.

Organizacijski načrt, ki je rezultat navedenih petih korakov,

DACUM

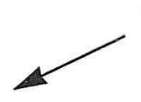

razčlenitev delovnih nalog

splošne naloge

delne naloge

posamezne naloge daje učitelju (mentorju) napotila, ki so mu v pomoč pri vodenju pouka. Ob upoštevanju napotkov lahko odgovori na naslednja bistvena vprašanja, ki se nanašajo na njegovo izobraževanje:

\section{Kakšen cilj imam?}

\section{Kako bom do njega prišel?}

\section{Kako bom vedel, da sem cilj dosegel?}

Končni cilj strokovnega izobraževanja je, da bo delavec, ki se ga je udeležil, zmožen uspešno opravljati delo na svojem delovnem mestu. Naloga učitelja (mentorja) je posredovati udeležencem učnega procesa izkušnje, ki jim bodo pomagale uspešno opravljati izbrani poklic. Tisti učitelj (mentor), ki je izdelal in določil cilje izobraževanja in ki sistematično načrtuje oblike izobraževanja, s katerimi bo cilje dosegel, bo najverjetneje uspešen.

\section{Razčlenifev delovnih nalog}

Postopek DACUM se je uveljavil, ko je bila ugotovljena potreba po novih strokovnoizobraževalnih tečajih oziroma po posodobitvi zastarelih tečajev. Kakor hitro so se odločili izdelati nove učne načrte, je prišlo do razčlenjevanja delovnih nalog.

Razčlenitev delovnih nalog natančno določa, kakšne naloge opravlja delavec na delovnem mestu in česa se mora zato udeleženec v izobraževanju (bodoči zaposleni delavec) naučiti. Razčlemba je izdelana na podlagi učne metode t. i. delavnice in preide $\mathrm{v}$ tabelo, grafično ponazoritev določenega poklica, kakršen je v praksi.

Delavnic (ki trajajo od enega do treh dni) se udeležuje od 10 do 15 ljudi. Udeleženci so večinoma praktiki iz določenega poklica in imajo natančno predstavo o dejavnostih in nalogah na delovnem mestu. Seznanjeni so tudi z najnovejšo tehnologijo v tej stroki. V idealnem primeru so ljudje iz prakse izbrani tako, da predstavljajo različne delovne položaje in široko skalo odgovornosti in nalog na delovnem mestu. Naslednji v tej vrsti udeležencev so strokovni učitelji (mentorji), ki so v vlogi svetovalcev. To skupino vodi posebej izurjen usklajevalec delavnic DACUM, čigar naloga je omogočati in usmerjati prispevke in delo udeležencev $\mathrm{v}$ delavnici. Ni nujno, da je usklajevalec strokovnjak v določenem poklicu, mora pa imeti izkušnje pri razčlenjevanju delovnih nalog, pri sestavljanju učnih načrtov in v učnem procesu skupinske dinamike.

Udeleženci učne delavnice se morajo najprej dogovoriti o imenu delovnega področja ter o obsegu dela v določenem poklicu.

Pri drugem koraku izdela skupina širok okvir delavčevih nalog in odgovornosti, ki so označene kot področja splošnih pris- 


\section{Shema iz sistema DACUM - poklicna smer natakar}

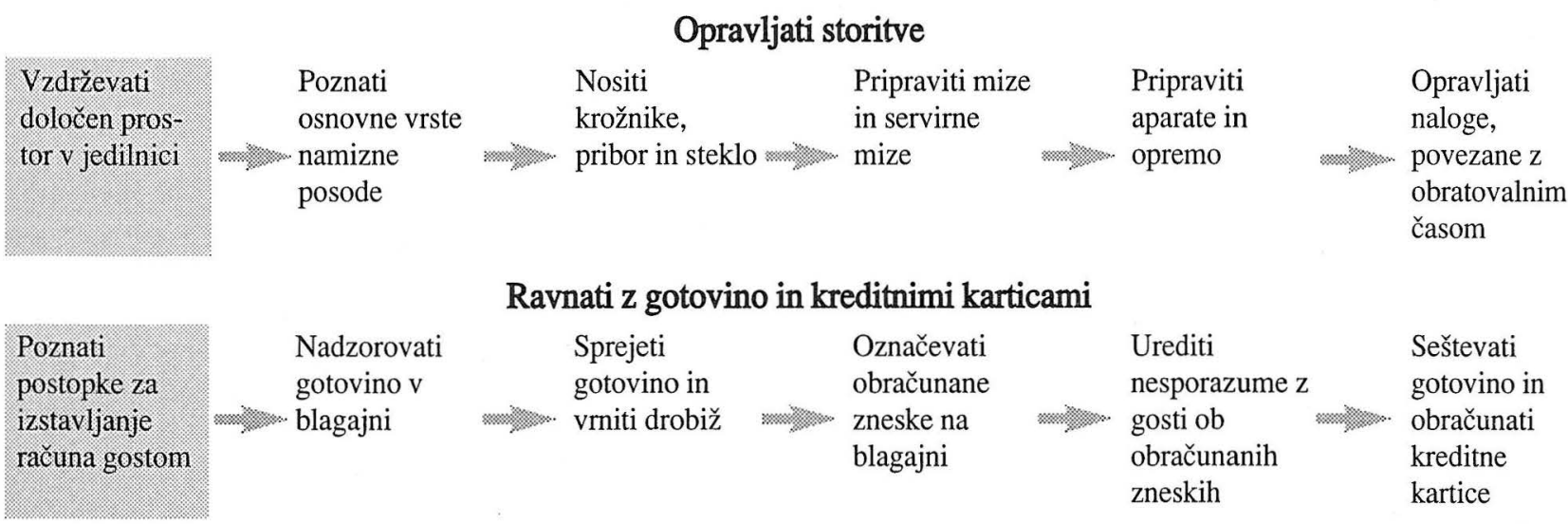

tojnosti. Tako bi na primer v okviru splošnih pristojnosti za poklicno smer »natakar« navedli naslednje naloge:

- komuniciranje s sodelavci in naročniki,

- vzdrževanje zdravstveno-sanitarne in varnostne oblike dela,

- opravljanje storitev,

- metode pri prodajanju in naročanju jedi in pijač,

- strežba jedi,

- strežba pijač,

- ravnanje z gotovino in kreditnimi karticami,

- opravljanje naloge gostitelja.

Nadalje je vsako izmed področij splošnih nalog razčlenjeno še na posebne delne naloge, ki jih zaposleni delavec opravlja na delovnem mestu. Tako je na primer pri poklicu natakarja navedena cela vrsta delnih nalog pod točko »opravljati storitve«:

- poznati osnovne vrste namizne posode, pribora in opreme,

- nositi krožnike, pribor in steklo,

- vzdrževati določen prostor $\mathrm{v}$ jedilnici

- pripravljati mize in servirne mize $\mathrm{v}$ jedilnici,

- pripravljati mize in servirne mize v banketni dvorani,

- pripravljati opremo in aparate za vsakdanje delo,

- opravljati naloge, ki so povezane z obratovalnim časom.

Členitev na specifične delne naloge je vnesena v tabelo, ki kaže realno sliko obravnavane poklicne smeri.

Izobraževanje mora obsegati vse značilne naloge, ki jih mora zaposleni opravljati na delovnem mestu. Te naloge morajo biti prirejene za raznolike delovne položaje določene poklicne smeri, kajti udeleženci v strokovnem izobraževanju se ne pripravljajo le na zaposlitev v enem podjetju ali le na en delovni položaj.

To poklicno smer bo kasneje preverjala skupina strokovnih učiteljev in strokovnjakov iz prakse, da bi bile naloge pravilno izbrane.

\section{Določitev storilnostnih cillev}

Po preverjanju so naloge razčlenjene v zelo specifične korake.

Tako je bila na primer v izobraževalnem programu pri poklicu natakar naloga »napisati in oceniti naročila gostov« razčlenjena v naslednje značilne korake:

- uporabljati kratice, ki jih za jedi in pijače na jedilnem listu uporablja podjetje,

- natančno določiti posebne zahteve gosta,

- nemudoma popraviti napake v naročilu ali pri cenah,

- upoštevati pravila podjetja glede razdelitve natakarjev in miz.
Pripravljalec tečaja uporabi te podatke pri odločitvah o tem, kakšne storilnostne cilje naj postavi.

Storilnostni cilji določajo, da bo udeleženec tečaja zmožen opravljati posebne naloge, $\mathrm{v}$ določenih razmerah in glede na posebna merila oziroma norme. Storilnostni cilji natančno določajo, kakšni morajo biti rezultati izobraževanja (mentorstva). Proces lahko prikažemo s formulo:

\section{udeleženec + naloge + pogoji + merila = storilnostni cilj}

Storilnostni cilj »napisati in oceniti naročila gostov « bi bil lahko izpisan takole: udeleženec čitljivo in brez napak zapiše naročila štirih gostov pri eni mizi, pri čemer uporablja ustrezne kratice podjetja.

Drugi cilj iz tega učnega načrta, ki se glasi »pripraviti sladice za serviranje «, je razčlenjen v podrobnejša opravila:

- preložiti sladico s pladnja na krožnik, ne da bi bila sladica poškodovana,

- uporabljati ustrezne krožnike, steklo, pribor,

- dodati sladici ustrezne obloge,

- velikost porcije uskladiti s pravili podjetja.

Pri tej nalogi bi storilnostni cilj definirali nekako takole: udeleženec pripravi za serviranje katero koli sladico iz predpisanega seznama, upoštevaje pri tem pravilno velikost porcije, ustrezno oblogo in pribor.

Profil poklicne smeri iz sistema DACUM in definicija storilnostnih ciljev sta odvisna od prizadevanja skupine ljudi iz prakse določenega poklicnega področja, od strokovnjakov, ki pripravljajo učne načrte in od pripravljalcev tečaja. Vendar s tem procesa še ni konec. Izdelani profil poklicne smeri in storilnostni cilji so izročeni učitelju (mentorju), ki mu to gradivo pomaga $\mathrm{v}$ odločitvah pri oblikovanju in vodenju tečaja.

Definiranje storilnostnih ciljev je uporabno za učitelja (mentorja) pri načrtovanju izobraževanja. Vsebina storilnostnih ciljev odloča pri določanju norme, kaj mora udeleženec strokovnoizobraževalnega tečaja znati, s tem pa daje dobro podlago za načrtovanje pri vrednotenju izobraževanja in zmožnosti, ki si jih je udeleženec pridobil. Učitelju je definicija storilnostnih ciljev lahko tudi pripomoček pri izbiranju strategije pouka in učnega gradiva, opreme in sredstev.

\section{Izbiranje postopkov pri vrednotenju}

Če želi učitelj ugotoviti, ali je udeleženec osvojil potrebno strokovno znanje, mora spremljati njegovo opravljanje različnih nalog v določenem poklicu. Sistem DACUM opremi učitelja z 
analizo podatkov o poklicni smeri in s storilnostnimi cilji, ki določajo norme, kakršne lahko od udeležencev pričakujemo. Merila, ki so postavljena za vsak storilnostni cilj, so povsem v skladu s predpisanimi normami delodajalca.

Učitelj (mentor) pripravi vrsto preizkusov za vsakega od postavljenih ciljev in preverja, ali so jih udeleženci dosegli ali ne.

\section{Izbiranje primernih učnih metod}

Učitelj (mentor) v strokovnem izobraževanju dela z raznolikimi posamezniki, ki so različne starosti, izhajajo iz različnega okolja, imajo različne delovne izkušnje, različno stopnjo izobrazbe, različne zmožnosti in poklicne cilje.

Učitelj mora izobraževanje načrtovati tako, da vsak udeleženec lahko doseže postavljene cilje.

$\mathrm{Da}$ bi izobraževanje lahko načrtoval, mora učitelj (mentor) razdeliti tečaj na obvladljive dele. Tradicionalni pristop je pri načrtovanem izobraževanju upošteval postopek razporejanja učne snovi, ki je temeljil na zaporedju predmetov. V sistemu DACUM pa je načrt pouka izdelan na podlagi storilnostnih ciljev, torej glede na to, kaj naj se udeleženec tečaja nauči.

Učitelj (mentor) lahko načrt uporabi za učenje tistega, kar naj bi udeleženci dosegli. To, česar naj bi se udeleženci naučili, vpliva tudi na izbiranje metod pri izobraževanju.

$\mathrm{V}$ primeru naše poklicne smeri bi bilo pri natakarju med storilnostnimi cilji zapisano tudi: izkazana je zmožnost udeleženca v posebnih položajih, ko gre za ravnanje s telesno prizadetimi in starejšimi gosti v restavraciji.

Jasno je, da mora biti tečajniku dana možnost, da se vadi v teh nalogah, če naj doseže predpisani storilnostni cilj. Učitelj bo v tem primeru verjetno izbral metodo igranih vlog, da bi udeležencem omogočil vaje v pridobivanju takih izkušenj.

Učitelj upošteva značilnosti udeležencev in tudi ovire oziroma pozitivne strani določenega okolja, kar seveda vpliva na njegove končne odločitve pri izbiranju učnih metod.

Organizacija tečaja temelji na storilnostnih ciljih, zato je učitelju (mentorju) laže uveljavljati individualizacijo pouka. Skupinske metode - npr. diskusijske skupine, igralne vloge - in predavanja imajo še zmeraj svoje mesto v izobraževanju. Seveda so deli v izobraževalnem procesu lahko organizirani tudi tako, da vsak udeleženec dela samostojno ali v majhni skupini; mentor pri tem lahko posveti več časa in pozornosti udeležencem, ki potrebujejo posebno pomoč. Tisti udeleženci, ki dosežejo posamične storilnostne cilje, preidejo k naslednjim; udeleženci, ki jim gre učenje bolj počasi, pa imajo več časa, da dosežejo cilje.

\section{Izbiranje izobraževalmih sredstev}

Učitelj izbere opremo, aparate, gradivo, diagrame, ilustracije, poglavja iz učbenikov, diapozitive, videoposnetke in filme. Udeleženci imajo različne zmožnosti dojemanja učne snovi. Nekateri so dojemljivejši za govorjeno razlago, drugi za ilustracije in tiskovno gradivo. Zato naj bo izbiranje dosegljivih sredstev široko, da bo zajelo vsa učila, ki ustrezajo različnim potrebam udeležencev.

Ko učitelj načrtuje in vodi izobraževanje, je postavljen pred mnoge odločitve. Sistem DACUM mu daje na razpolago analizo določene poklicne smeri in definicije storilnostnih ciljev, ki so mu v pomoč pri kritičnih korakih v usmerjanju pouka in njegovih ciljev.

Pristop DACUM ponuja učitelju (mentorju) metodo, ki je specifična a tudi dovolj prožna za prilagajanje različnim izobraževalnim položajem.

\section{dr. Jindra Kulich}

dosedanji direktor Centra za dopolnilno izobraževanje na Univerzi v Vancouvru

\section{Liferatura}

Centre for Continuing Education, University of British Columbia. DACUM: Overview. Victoria: Ministry of Education, British Columbia, n.d. 14pp.

DACUM: Job analysis. Victoria: Ministry of Education, B.C., n.d. 13 pp. DACUM: Performance objectives. Victoria: Ministry of Education, B.C., n.d. $14 \mathrm{pp}$.

DACUM: Instructional Techniques. Victoria: Ministry of Education, B.C., n.d. $15 \mathrm{pp}$.

DACUM: Instructional resources. Victoria: Ministry of Education, B.C., n.d. $12 \mathrm{pp}$.

DACUM: Evaluation. Victoria: Ministry of Education, B.C., n.d. 13 pp. 